\title{
PERSEPSI ORANG TUA TENTANG KEKERASAN SEKSUAL PADA ANAK DI KARANGANYAR RT 03/RW 01 KELURAHAN BANYUMANIK KOTA SEMARANG
}

\author{
Siti Nur Umariyah Febriyanti ${ }^{1}$, Ni Wayan Diah Darmayanti ${ }^{2}$ \\ STIKes Karya Husada Semarang \\ Email :snu.febriyanti@gmail.com \\ Email: diahdarmayanti28@yahoo.com
}

\begin{abstract}
Abstrak
Latar belakang: Kekerasan seksual merupakan hubungan atau interaksi antara seorang anak dengan orang yang lebih tua atau orang dewasa seperti orang asing, saudara sekandung atau orang tua dimana anak dipergunakan sebagai objek pemuas kebutuhan seksual pelaku. Kota Semarang menduduki peringkat ketiga dengan 42 kasus kekerasan seksual pada anak dari 35 kabupaten di Jateng. Studi pendahuluan yang didapatkan dari Bapermas sub bidang PPA Kecamatan Banyumanik Kota Semarang di Karanganyar Rt 03/Rw 01 Kelurahan Banyumanik terdapat 1 kasus kejadian kekerasan seksual pada anak di tahun 2015 anak tersebut masih berumur 14 tahun. Tujuan penelitian: mengeksplorasi persepsi orang tua tentang kekerasan seksual pada anak di Karanganyar Rt 03/Rw 01 Kelurahan Banyumanik Kota Semarang. Metode penelitian: Desain penelitian yang digunakan penelitian Kualitatif dengan pendekatan fenomenologi. Partisipan dalam penelitian ini adalah orang tua yang memiliki anak usia 9-12 tahun. Dalam penelitian ini menentukan jumlah populasi dengan saturasi data.Instrumen dalam penelitian ini adalah peneliti sendiri. Hasil penelitian: Dari 6 tujuan khusus yang telah ditetapkan, telah terjadi kesaturasian data pada setiap tujuan khusus. Kesimpulan: Orang tua memiliki pemahaman yang baik tentang kejahatan seksual pada anak. Saran: Untuk itu, disarankan kepada orang tua agar memberikan pendidikan seks dini kepada anak sejak umur 5 tahun di mana pendidikan seks dini meliputi memberitahu anatomi organ genital dan siapa saja yang boleh menyentuh tubuh anak tersebut.
\end{abstract}

Kata kunci : persepsi orang tua; kekerasan seksual pada anak

\section{Perceptions of Parents about Sexual Abuse on Children in Karanganyar RT 03 / RW 01 Banyumanik Subdistrict, Semarang City.}

\begin{abstract}
Background: Sexual abuse is a relationship or interaction between a child and an older person or adult like a stranger, sibling or parent where the child is used as an object of satisfying the needs of sexual perpetrators. Semarang city occupies third position with 42 cases of sexual abuse on children of 35 districts in Central Java. Preliminary studies were obtained from Bapermas sub-sector of PPA Banyumanik District of Semarang in Karanganyar RT 03 / RW 01. Banyumanik Subdistrict there is one case of child sexual abuse incident in 2015, the child was 14 years old. The aim of study: was to explore the perception of parents about the sexual abuse of children in Karanganyar RT 03 / RW 01 Banyumanik Subdistrict, Semarang City. Methods: The study design used qualitative research with phenomenological approach. Participants in this study are the parents who have children aged 9-12 years old. In this study determines the amount of population with saturation of data. Instrument in this study is the researchers themselves. Results: From the sixth purposes that has been agreed, it has been data compatible in each specific purpose. Conclusion: The parents have a good understanding about sex abuse of children. Suggestion: There for, it is suggested to parents to provide early sex education to children from the age of 5 years in which early sex education includes telling anatomical genital organ and anyone is allowed to touch the body of the child.
\end{abstract}

Key words : the perception of parents; sexual abuse on children 


\section{Pendahuluan}

Dalam kamus umum bahasa Indonesia, karangan Purwadarminta, kekerasan diartikan sebagai sifat atau hal yang keras, kekuatan, paksaan. Sedangkan paksaan berarti tekanan, desakan yang keras. Jadi, kekerasan berarti membawa kekuatan, paksaan dan tekanan. Salah satu jenis kekerasan terhadap anak yaitu kekerasan seksual, kekerasan seksual meliputi pemaksaan hubungan seksual yang dilakukan terhadap orang yang menetap dalam lingkup rumah tangga tersebut (seperti istri, anak, dan pekerja rumah tangga ${ }^{[8]}$. Kekerasan seksual menurut End Child Prostitusion in Asia Tourism (ECPAT) Internasional merupakan hubungan atau interaksi antara seorang anak dengan seorang yang lebih tua atau orang dewasa seperti orang asing, saudara sekandung atau orang tua dimana anak dipergunakan sebagai objek pemuas kebutuhan seksual pelaku. Kasus kekerasan seksual terhadap anak merupakan salah satu kasus yang mengalami peningkatan secara signifikan belakangan ini ${ }^{[3]}$.

Kota semarang berdasarkan data dari BP3AKB (Badan Pemberdayaan Perlindungan Perempuan Anak dan Keluarga Berencana) mencatat sepanjang tahun 2015 kekerasan seksual pada anak terdapat 42 kasus. Di mana Kota Semarang menduduki peringkat ke tiga kasus kekerasan seksual pada anak dengan rentang usia 0-18 tahun merupakan korban dari kekerasan seksual pada anak. Studi pendahuluan yang didapatkan dari Bapermas (Badan Pemberdayaan Masyarakat) sub bidang perlindungan perempuan dan anak Kecamatan Banyumanik Kota Semarang di Karanganyar Rt 03/Rw 01 Kelurahan Banyumanik terdapat 1 kasus kejadian kekerasan seksual pada anak di tahun 2015 anak tersebut masih berumur 14 tahun. Berdasarkan hasil wawancara di Karanganyar Rt 03/Rw 01 Kelurahan Banyumanik Kota Semarang didapatkan hasil dari 3 orang tua 2 orang mengatakan kekerasan seksual merupakan tindakan pemerkosaan yang dilakukan oleh orang yang tidak dikenal, tindakannya berupa memasukkan organ intim ke kelamin anak, pencegahan kekerasan seksual pada anak dengan cara memantau anak di rumah dan di sekolah, ciri-ciri anak yang mengalami tindakan kekerasan seksual yaitu anak merasa kesakitan di bagian kemaluannya. Respon yang diberikan oleh orang tua saat akan di wawancara bingung menjawab dan masih menganggap hal tersebut tabu untuk di utarakan. Sedangkan 1 orang tua lain memberikan respon yang positif dan telah sering membaca buku agar anaknya terhindar dari tindakan kekerasan seksual 
Berkaitan dengan hal tersebut, peneliti ingin mengetahui "Persepsi Orang Tua Tentang Kekerasan Seksual Pada Anak di Karanganyar Rt 03 Rw 01 Kelurahan Banyumanik Kota Semarang". Peneliti merasa tertarik meneliti objek tersebut untuk mengetahui apakah orang tua memiliki persepsi yang sama atau berbeda tentang kekerasan seksual terhadap anak. Berdasarkan uraian latar belakang di atas, dapat dirumuskan suatu permasalahan, yaitu bagaimanakah persepsi orang tua tentang kekerasan seksual pada anak di Karanganyar Rt 03/Rw 01 Kelurahan Banyumanik Kota Semarang? Sesuai dengan rumusan masalah di atas, tujuan dari penelitian ini, yaitu mengeksplorasi persepsi orang tua tentang kekerasan seksual pada anak di Karanganyar Rt 03/Rw 01 Kelurahan Banyumanik Kota Semarang. Tujuan khusus penelitian ini, yaitu (1) mengeksplorasi persepsi orang tua tentang pengertian kekerasan seksual, (2) mengeksplorasi persepsi orang tua tentang siapa saja yang dapat menjadi pelaku kekerasan seksual, (3) mengeksplorasi persepsi orang tua tentang pedophilia, (4) mengeksplorasi pesepsi orang tua tentang dampak kekerasan seksual terhadap anak, (5) mengeksplorasi persepsi orang tua tentang perubahan perilaku anak korban kekerasan, dan (6) mengeksplorasi persepsi orang tua tentang penanganan kekerasan seksual pada anak.

\section{Tinjauan Teoretis}

Persepsi adalah seluruh proses akal manusia yang sadar dalam menggambarkan tentang lingkungan sekitarnya ${ }^{[4]}$. Persepsi adalah kemampuan untuk membeda-bedakan, mengelompokan, memfokuskan suatu objek yang ada di lingkungan sekitarnya ${ }^{[12]}$. Persepsi adalah pengalaman tentang objek, peristiwa atau hubungan yang diperoleh dengan menyimpulkan informasi dan menafsirkan pesan. Persepsi ialah memberikan makna pada stilumulus inderawi (sensory stimuli) ${ }^{[9]}$. Berdasarkan beberapa pendapat di atas dapat ditarik kesimpulan bahwa persepsi adalah proses pemahaman ataupun pemberian makna atas suatu informasi terhadap proses penginderaan terhadap objek, peristiwa, atau hubungan-hubungan antar gejala yang selanjutnya di proses oleh otak.

Orang tua adalah pendidik menurut kodrat yakni pendidik pertama dan utama karena secara kodrati anak manusia dilahirkan oleh orang tuanya (ibunya) dalam keadaan tidak berdaya. Pengertian orang tua menurut Kartono dalam Astrida Orang tua adalah pria dan wanita yang terikat dalam perkawinan dan siap sedia untuk memikul tanggung jawab sebagai ayah dan ibu dari anak-anak yang dilahirkannya. Orang tua adalah setiap orang yang bertanggung jawab dalam suatu keluarga atau tugas rumah tangga yang dalam kehidupan sehari-hari disebut sebagai bapak dan $\mathrm{ibu}^{[2]}$. Kemudian menurut Gunarsa dalam Astrida 
menyatakan bahwa Orang tua adalah dua individu yang berbeda memasuki hidup bersama dengan membawa pandangan, pendapat dan kebiasaan-kebiasaan sehari-hari. Berdasarkan pendapat para ahli di atas maka dapat disimpulkan orang tua adalah pria dan wanita yang terikat dalam perkawinan yang sah dan hidup bersama berperan sebagai ayah dan ibu bagi anak-anaknya dan bertanggung jawab dalam kehidupan sehari-hari sebagai pendidik yang pertama dan utama serta memenuhi segala kebutuhan anak-anaknya.

Kekerasan seksual terhadap anak adalah apabila seseorang menggunakan anak untuk mendapatkan kenikmatan atau kepuasan seksual. Tidak terbatas pada hubungan seks saja, tetapi juga tindakan-tindakan yang mengarah kepada aktivitas seksual terhadap anak-anak, seperti:

(1) Menyentuh tubuh anak secara seksual, baik si anak memakai pakaian atau tidak.

(2) Segala bentuk penetrasi seks, termasuk penetrasi ke mulut anak menggunakan benda atau anggota tubuh.

(3) Membuat atau memaksa anak terlibat dalam aktivitas seksual, secara sengaja melakukan aktivitas seksual dihadapan anak, atau tidak melindungi dan mencegah anak menyaksikan aktivitas seksual yang dilakukan orang lain.

(4) Membuat, menditribusikan dan menampilkan gambar atau film yang mengandung adegan anak-anak dalam pose atau tindakan tidak senonoh.

(5) Serta memperlihatkan kepada anak gambar, atau film yang menampilkan aktivitas seksual $^{[10]}$

\section{Metode Penelitian}

Metode penelitian yang digunakan dalam penelitian ini adalah kualitatif. Penelitian ini menggunakan pendekatan fenomenologi, yaitu peneliti dengan cara menangkap dan menggali fenomena atau gejala yang timbul dari obyek yang diteliti ${ }^{[6]}$. Sampel dalam penelitian kualitatif bukan dinamakan responden, tetapi partisipan/ informan dalam penelitian ${ }^{[11]}$. Partisipan dalam penelitian ini adalah orang tua yang memiliki anak usia 9-12 tahun yang sesuai kriteria dan pemilihannya dibantu oleh key person. Pengambilan sampel dalam penelitian ini menggunakan metode purposive sampling, di mana purposive sampling adalah metode pemilihan partisipan dalam suatu penelitian dengan menentukan terlebih dahulu kriteria yang akan dimasukan dalam penelitian. Dalam hal ini, partisipan yang diambil dapat memberikan informasi yang berharga bagi peneliti ${ }^{[11]}$. Dalam penelitian ini yang menjadi key person adalah Ketua RT. 
Instrumen dalam penelitian kualitatif adalah peneliti itu sendiri, setelah fokus menjadi jelas maka baru dikembangkan dalam bentuk instrumen sederhana yang dapat melengkapi data dan membandingkan dengan kata yang telah ditemukan dalam observasi dan wawancara $^{[13]}$. Di samping itu, digunakan juga instrumen wawancara mendalam. Wawancara dalam penelitian ini dilakukan 15-30 menit yang bertujuan untuk mengeksplorasi persepsi orang tua tentang kekerasan seksual pada anak di Karanganyar Rt 03/Rw 01 Kelurahan Banyumanik Kota Semarang. Dalam penelitian ini, peneliti juga menggunakan alat perekam dan buku catatan. Alat perekam digunakan sebagai alat bantu agar tidak ada informasi yang terlewatkan dan selama wawancara, sedangkan buku catatan digunakan untuk mencatat hasil observasi baik lingkungan saat wawancara maupun ekspresi partisipan saat wawancara.

Ada beberapa tahapan dalam mengumpulkan data, yaitu tahap persiapan, tahap wawancara, dan tahap penutup. Selanjutnya, cara pengolahan data. Pengolahan data ini menggunakan analisis kualitatif. Analisis kualitatif ini dilakukan melalui cara induktif, yakni pengambilan kesimpulan umum berdasarkan hasil-hasil observasi yang khusus ${ }^{[7]}$. Pengolahan data kualitatif dilakukan dengan tiga langkah, yaitu reduksi data (data reduction), penyajian data (data display) dan penarikan kesimpulan (conclusion drawing and verification). Dalam pelaksanaan reduksi data, penyajian data, dan penarikan kesimpulan/ verifikasi, merupakan langkah yang luwes, dalam arti tidak terikat oleh batasan kronologi. Secara keseluruhan langkah-langkah tersebut saling berhubungan selama dan sesudah pengumpulan data ${ }^{[1]}$.

\section{Hasil Penelitian}

1. Persepsi orang tua (ayah atau ibu) mengenai pengertian kekerasan seksual

Hasil penelitian menunjukkan bahwa pemahaman orang tua terkait dengan kekerasan seksual pada anak cukup baik. Orang tua sudah memahami hakikat dari kekerasan seksual pada anak yang disampaikan melalui pernyataan-pernyataan bahwa kekerasan seksual pada anak merupakan perbuatan yang tidak baik kepada anak di bawah umur sehingga menyebabkan si anak mengalami sakit secara fisik dan mental. Tidak hanya itu, orang tua juga mengetahui bentu-bentuk kekerasan seksual pada anak yang meliputi pemerkosaan dan pencabulan.

2. Persepsi orang tua (ayah atau ibu) tentang siapa saja yang dapat menjadi pelaku kekerasan seksual

Hasil penelitian menunjukkan bahwa orang tua sudah menyadari bahwa orang-orang yang berpotensi melakukan kekerasan seksual pada anak adalah orang-orang yang memiliki 
hubungan baik dan dekat dengan anak, seperti keluarga dan tetangga. Pendapat tersebut diperkuat oleh pernyataan yang disampaikan oleh T1 dan T2 serta T3 yang menyatakan bahwa yang menjadi pelaku kekerasan seksual pada anak justru lebih banyak orang-orang terdekat, salah satu contohnya adalah keluarga. Dalam hal ini, yang menyebabkan keluarga menjadi salah satu pelaku kekerasan seksual terhadap anak adalah faktor ekonomi, yaitu bapak bercerai dengan istrinya sehingga nafsu seksualnya dilampiaskan ke anak. Di samping itu, bisa juga karena bapak mengalami gangguan mental sehingga dia tega menganiaya dan mencabuli anaknya.

3. Persepsi orang tua (ayah atau ibu) tentang pedophilia

Hasil penelitian menunjukkan bahwa orang tua memiliki pemahaman yang baik mengenai pedophilia. Orang tua sudah mengerti definisi dari istilah pedophilia. Dalam hal ini, mereka menyatakan bahwa pedophilia merupakan kelainan seksual pada orang dewasa yang menjadikan anak-anak sebagai sasarannya. Pendapat tersebut diperkuat oleh pernyataan yang disampaikan oleh T2 dan T3 yang menyatakan bahwa pedophilia merupakan kelainan seksual yang menyimpang pada orang dewasa yang orientasinya mengarah pada anak-anak.

4. Pesepsi orang tua (ayah atau ibu) tentang dampak kekerasan seksual terhadap anak

Orang tua menyatakan bahwa dampak negatif akan terjadi jika anak mengalami kekerasan seksual, seperti malu, minder, pendiam, dan trauma. Kekerasan seksual cenderung menimbulkan dampak traumatis baik pada anak maupun pada orang dewasa. Namun, kasus kekerasan seksual sering tidak terungkap karena adanya penyangkalan terhadap peristiwa kekerasan seksual yang terjadi. Lebih sulit lagi adalah jika kekerasan seksual ini terjadi pada anak-anak, karena anak-anak korban kekerasan seksual tidak mengerti bahwa dirinya menjadi korban. Pendapat yang sama juga disampaikan oleh T1, T2, dan T3, bahwa kekerasan seksual sangat berdampak buruk bagi anak yang mengalaminya, seperti trauma, malu, prestasi belajar menurun, minder.

5. Persepsi orang tua (ayah atau ibu) tentang perubahan perilaku anak korban kekerasan

Sesuai dengan hasil penelitian, bahwa orang tua juga memahami tanda-tanda apabila terjadi tindakan kekerasan seksual pada anak. Mereka menyatakan bahwa tanda-tanda seorang anak mengalami kekerasan seksual, yaitu anak akan murung, kesakitan pada alat vitalnya, dan merasa ketakutan bila bertemu dengan orang lain. Begitu pula pendapat yang disampaikan oleh T1 dan T2 yang lebih menekankan bahwa tanda-tanda seorang anak mengalami kekerasan seksual, yaitu anak akan sering melamun. Ada sejumlah tanda psikis maupun fisik 
yang terlihat pada anak-anak korban kekerasan seksual. Berikut ini adalah tanda-tanda psikis dan fisik pada anak korban kekerasan seksual.

6. Persepsi orang tua (ayah atau ibu) tentang penanganan kekerasan seksual pada anak.

Hasil penelitian menunjukkan bahwa orang tua memiliki pemahaman yang baik terhadap bagaimana peranan keluarga, masyarakat, dan pemerintah dalam menangani kasus kekerasan seksual pada anak. Mereka menyatakan bahwa peranan keluarga dalam menangani kasus kekerasan seksual pada anak, yaitu harus diberikan pengertian dan pemahaman dalam berperilaku, anak diberikan pendidikan seks sejak dini, dan dibekali iman atau pendidikan agama sehingga anak bisa menutup aurat dan menjaga dirinya. Di samping itu, masyarakat juga memiliki perenan penting dalam menjaga anak-anak di lingkungannya. Dalam hal ini, orang tua menyatakan bahwa masyarakat harus selalu mengawasi dan menasehati agar anak selalu berhati-hati dalam bergaul. Orang tua juga menyatakan bahwa anak yang menjadi kekerasan seksual perlu mendapatkan perlindungan hukum. Pendapat tersebut diperkuat oleh pernyataan T3 yang menyatakan bahwa korban kekerasan seksual harus mendapatkan perlindungan hukum agar kekerasan seksual terhadap anak dapat berkurang.

\section{Pembahasan}

Pemahaman orang tua terkait dengan kekerasan seksual pada anak cukup baik. Pemahaman yang cukup baik mengenai kekerasan seksual ditunjukkan oleh dua partisipan yang menyampaikan pernyataan yang sesuai dengan definisi kekerasan seksual, sedangkan pernyataan dua partisipan yang lain menyimpang dari definisi tersebut. Pernyataan juga diperkuat oleh T2 yang menyatakan bahwa "Kekerasan seksual merupakan tindakan atau perbuatan yang menyimpang dan tidak menyenangkan pada si anak, seperti memegang, mencium dan paksaan yang dilakukan sehingga anak merasa tidak nyaman. Kalau perbuatan tersebut tidak nyaman untuk si anak, hal itu tergolong kekerasan seksual. Contohnya adalah membuka baju si anak dengan paksaan." Hal ini sejalan dengan pernyataan End Child Prostitusion in Asia Tourism (ECPAT) Internasional bahwa kekerasan seksual pada anak merupakan hubungan atau interaksi antara seorang anak dengan seorang yang lebih tua atau orang dewasa seperti orang asing, saudara sekandung atau orang tua di mana anak dipergunakan sebagai objek pemuas kebutuhan seksual pelaku. Perbuatan ini dilakukan dengan menggunakan paksaan, ancaman, suap, tipuan, bahkan tekanan. Kegiatan-kegiatan kekerasan seksual terhadap anak tersebut tidak harus melibatkan kontak badan antara pelaku 
dengan anak sebagai korban. Bentuk-bentuk kekerasan seksual itu sendiri bisa dalam tindakan perkosaan ataupun pelecehan seksual ${ }^{[3]}$.

Orang tua juga sudah menyadari bahwa orang-orang yang berpotensi melakukan kekerasan seksual pada anak adalah orang-orang yang memiliki hubungan baik dan dekat dengan anak, seperti keluarga dan tetangga. Lyness ${ }^{[5]}$ menyatakan bahwa kekerasan seksual (sexual abuse) merupakan jenis penganiayaan yang biasanya dibagi menjadi dua kategori berdasarkan identitas pelaku yaitu (1) familial abuse, yaitu kekerasan seksual dimana antara korban dan pelaku masih dalam hubungan darah, menjadi bagian dalam keluarga inti. Dalam hal ini, termasuk seseorang yang menjadi pengganti orang tua, misalnya ayah tiri, pengasuh atau orang yang dipercaya merawat anak. (2) extra familial abuse, yaitu kekerasan yang dilakukan oleh orang lain di luar keluarga korban

Di samping itu, orang tua juga memahami bahwa anggota keluarga bisa saja menjadi pelaku kekerasan seksual pada anak karena adanya nafsu yang berlebihan dan kurangnya pengetahuan keagamaan. Menurut Lyness $^{[5]}$ kekerasan seksual terhadap anak meliputi tindakan menyentuh atau mencium organ seksual anak, tindakan seksual atau pemerkosaan terhadap anak, memperlihatkan media/ benda porno, menunjukkan alat kelamin pada anak dan sebagainya. Orang tua seharusnya bertanggung jawab dalam suatu keluarga atau tugas rumah tangga yang dalam kehidupan sehari-hari disebut sebagai bapak dan ibu dalam menjaga anaknya supaya terhindar dari tindakan kekerasan seksual ${ }^{[2]}$.

Orang tua memiliki pemahaman yang baik mengenai pedophilia. Orang tua sudah mengerti definisi dari istilah pedophilia. Menurut De Yong (2002), pedophilia dapat diartikan menyukai anak-anak. Kekerasan seksual dengan anak sebagai korban yang dilakukan oleh orang dewasa, dan yang menjadi korban utamanya adalah anak-anak. Di samping itu, dapat dikatakan bahwa orang tua juga sudah memahami siapa saja korban yang diincar oleh pelaku pedophilia. Dalam hal ini, orang tua mengerti bagaimana dan siapa yang diincar oleh pelaku pedophilia. Mereka menyatakan bahwa yang diincar oleh pelaku pedophilia adalah anak-anak yang masih duduk di bangku sekolah dasar. Menurut Adrianus E. Meliala ${ }^{[8]}$ ada beberapa kategori pedophilia, yaitu mereka yang tertarik dengan anak berusia di bawah 5 tahun disebut infantophilia. Sementara itu mereka yang tertarik dengan anak perempuan berusia 13-16 tahun disebut hebophilia, mereka yang tertarik dengan laki-laki di usia tersebut, dikenal dengan ephebohiles. Berdasarkan perilaku, ada yang disebut exhibitionism yaitu bagi mereka yang suka memamerkan, suka menelanjangi anak, atau disebut voyeurism yaitu suka masturbasi depan anak, atau sekedar meremas kemaluan anak. 
Pemahaman orang tua juga sangat baik mengenai tanda-tanda apabila terjadi tindakan kekerasan seksual pada anak. Mereka menyatakan bahwa tanda-tanda seorang anak mengalami kekerasan seksual, yaitu anak akan murung, kesakitan pada alat vitalnya, dan merasa ketakutan bila bertemu dengan orang lain. Begitu pula pendapat yang disampaikan oleh T1 dan T2 yang lebih menekankan bahwa tanda-tanda seorang anak mengalami kekerasan seksual, yaitu anak akan sering melamun. Ada sejumlah tanda psikis maupun fisik yang terlihat pada anak-anak korban kekerasan seksual. Berikut ini adalah tanda-tanda psikis dan fisik pada anak korban kekerasan seksual.

Terkait dengan penanganan kekerasan seksual pada anak, orang tua menyatakan bahwa peranan keluarga dalam menangani kasus kekerasan seksual pada anak, yaitu harus diberikan pengertian dan pemahaman dalam berperilaku, anak diberikan pendidikan seks sejak dini, dan dibekali iman atau pendidikan agama sehingga anak bisa menutup aurat dan menjaga dirinya. Lingkungan keluarga sangat memengaruhi bagi pengembangan kepribadian anak, dalam hal ini orang tua harus berusaha untuk menciptakan lingkungan keluarga yang sesuai dengan keadaan anak. Dalam lingkungan keluarga harus diciptakan suasana yang serasi, seimbang, dan selaras, orang tua harus bersikap demokrasi baik dalam memberikan larangan, dan berupaya merangsang anak menjadi percaya diri. Di samping itu, tetangga juga harus saling menjaga anak-anak di lingkungan sekitar. Anak yang menjadi kekerasan seksual perlu mendapatkan perlindungan hukum. Menurut ketentuan Undang-Undang Nomor 23 Tahun 2002 tentang perlindungan Anak pasal 64 (3) dan Undang-Undang Nomor 11 Tahun 2012 tentang sistem peradilan pidana Anak pasal 90 mengatur, anak sebagai korban berhak mendapatkan rehabilitasi dari lembaga maupun di luar lembaga.

\section{Simpulan}

Pemahaman orang tua terkait dengan pengertian kekerasan seksual, pelaku kekerasan seksual, pengertian pedophilia, dampak, perubahan perilaku, dan penanganan kekerasan seksual pada anak cukup baik.

\section{Saran}

Untuk itu, peneliti menyarankan kepada orang tua agar memberikan pendidikan seks dini kepada anak sejak umur 5 tahun di mana pendidikan seks dini meliputi memberitahu anatomi organ genital dan siapa saja yang boleh menyentuh tubuh anak tersebut. Dengan adanya pendidikan seks dini yang diterapkan orang tua kepada anaknya akan meminimalisir 
terjadinya kekerasan seksual pada anak karena anak sudah memahami perilaku yang boleh ataupun tidak boleh dilakukan.

\section{Daftar Pustaka}

[1] Agus Salim. 2009. Memahami Penelitian Kualitatif. Bandung: Alfabeta.

[2] Astrida. 2012. Perandan Fungsi Orang Tua dalam Mengembangkan Kecerdasan Emosiona Anak. http://sumsel.kemenag.go.id. diaksespada 29 Juli 2016.

[3] Hurairah, Abu. 2012. Kekerasan Terhadap Anak. Bandung: Nuasa Pers.

[4] Koentjaraningrat. 2011. Pengantar Antropologi. Jakarta: Rineka Cipta.

[5] Maslihah, Sri. 2006. Kekerasan Terhadap Anak: Model Transional dan Dampak Jangka Panjang (Jurnal Pendidikan Anak Usia Dini).

[6] Moelong, lexy. 2007. Metodologi penelitian kualitatif edisi revisi. Bandung: PT Remaja Rosdakarya.

[7] Notoadmodjo. 2010. Metode Penelitian Kesehatan. Jakarta : Rineka Cipta.

[8] Noviana, Ivo. 2015. Kekeraan seksual Terhadap Anak: Dampak Dan Penanganannya Child Sexual Abuse: Impanct and Hendling (PusatPenelitiandanPengembanganKesejahteraanSosial RI).

[9] Rakhmat, Jalaluddin. 2011. Psikologi Komunikasi. Bandung: PT Remaja Rosdakarya.

[10] Sari. 2009. Penyebab Kekerasan Seksual terhadap Anak dan Hubungan Pelaku dengan Korban. http://kompas.com/index.php/read/ xml/2009/01/28/. Diakses 8 Agustus 2016.

[11] Saryono. 2013. Metodologi Penelitian Kualitatif Dan Kuantitatif. Yogyakarta: Nuha Medika.

[12] Sarwono, Sarlito W. 2012. Pengantar Psikologi Umum. Jakarta: Rajawali Pers.

[13] Sugiyono. 2010. Metode Penelitian Kunatitatif Kualitatif dan R\&D. Bandung:Alfabeta

[14] Suryanto, Bagong. 2010. Masalah Sosial Anak. Jakarta: Penerbit Kencana. 